\title{
READERS
Insight
}

Journal of Management Info (JMI)

ISSN:2313-3376

www.readersinsight.net/jmi

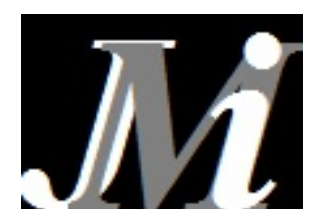

\section{How does stock prices respond to various macroeconomic factors? A case study of Pakistan}

\author{
Ayaz khan ${ }^{1 *}$ \\ ${ }^{1}$ Department of Economics University of Malakand KPK Pakistan \\ * Corresponding author: ayazaerc@yahoo.com
}

Abstract

Over the time everything flourished and at the same time the interrelationship among the stock market prices, returns and macroeconomic factors got attention of the researchers in the field of finance and economics around the world. In this respect, the current study is an attempt to investigate the response of various macroeconomic factors (GDP, Money Supply, inflation, exchange rate and Size of firm) toward stock market prices in case of Karachi stock exchange over a period of 1971 to 2012 . The study utilizes Autoregressive Distributed lag model (ARDL) technique. The results shows that in long run each factor significantly contribute to the stock price while in shot run some factors were significant while some were not but the error correction term shows significant convergence toward equilibrium. The findings of study suggest that for smoothness of stock market the current factors must be targeted.

Keywords: Stock Market Prices, Macroeconomic Factors, ARDL Technique

\section{ARTICLE INFORMATION}

Received: 25 August 2014

Revised: 25 November 2014

Accepted: 25 December 2014

DOI:

http://dx.doi.org//10.31580/jmi.v4i1.22

\section{Introduction and literature}

Like that of any other financial asset, the price of stock equates the present value of the stream of future cash payments to the owner. Shareholders cash payments are uncertain and subject the earning and performance of the firm. In contrast the cash payments to bondholders are less uncertain because they received a fixed contractual obligation. Main source of stockholders cash payments is dividends of the firm, these cash payments are paid out of earnings, and distribution resulting from liquidation or sale of assets. As price is named as the central of gravity of market in this regard current study is organized to investigate the impact of various macroeconomic factors on the share prices in case of an emerging economy Pakistan. Literature related to finance also focused on the pricing of common stocks and pricing of stock also remained as a great concern for financial economics and management. Starting from the mean variance portfolio model of Markowitz (1952) and generally accepted price theory also named as (CAPM) capital asset pricing Model introduced by Sharpe in 1964 and extended by Lintner (1965) and Mossin (1966). CAPM is simplified form of asset pricing theory which concentrates only on the stock market index for explaining stock returns. The basic version of capital asset pricing model has some restrictive assumptions and most of the criticism was made on these assumptions. One of these criticisms targets the sole role of market in the CAPM model. To answer the criticisms more factors were added to the CAPM and some assumptions were relaxed and due to these tactics multifactor model (MFM) emerged. Pioneered these studies were King (1966) and Merton (1973). These reforms does contribute to theories related to asset pricing but again beside other factors of pricing variable market return is the main variable in these models.

Soon after the criticisms and reforms about factors other than market. Arbitrage pricing theory (ATP) was introduced to compromise the problems of CAPM but not employed other factors (Ross 1976). The ATP introduced the use of factors without pre-specification of selected factors for the model, but soon ATP was encountered by critics. One of the major criticisms was that of about the factor statistical derivation and no clear specification or in other word the critics says that ATP could not specify the factors but just statistically derived them. Further the critics say that in factor analysis the factors should be economic aggregates like GDP inflation or interest rate. In this regards Chen, Roll and Ross (1986) firstly used macroeconomic factors as proxies for the unspecified factors in the ATP.

In 1986 Chen, Roll and Ross functioned equity return by macroeconomic factors. This new model is also named "Macroeconomic Factor Model" (MFM). As economic fluctuations do affect the discount rate and dividends, it is accomplished that macroeconomic factors systematically affect the stock return. It is expected that discount rate vary with the risk premium levels, interest rate and term structure. The future dividends of a firm may change due to fluctuation in inflation rate, consumption and real production and oil prices. His new model MFM does shows some significant advantages over the traditional APT, also MFM can gives economic interpretation and explanation whereas it was not simple in the derived factor model ATP. Nonetheless this new model has its own disadvantages that nonexistence of theoretical framework for the selection of these macro-economic factors.

Arbitrage price theory (APT) (Ross 1976) can link macroeconomic factors and stock market return. It explains asset return by multiple risk factors. While most of the empirical work on ATP paying attention to individual security returns this may also be utilized in aggregate stock market framework. As regarding the future returns of a firm a change in macroeconomic factors can change the underlying risk factor.

A number of studies were done around the globe regarding the relationship linking macroeconomic variables and stock prices such as 
Fama (1981 and 1990), Fama and French (1989), Shwert (1990), Ferson and Harvy (1991), Black, Fraser and MacDonald (1997). All these studies reached to same conclusion that there exist a significant relationship among macroeconomic factors, such as inflation, interest rate, industrial production, risk premium measures and stock prices. Alternatively stock returns and macro-economic factors can be link through (PVM) Present Value Model. As PVM model relate expected future cash flows and the discounted future rate of cash flows to stock prices. In other words all those macroeconomic factors that affect the discount rate by which the discounted cash flows or future expected cash flows should have influence the stock market return and prices. One of the advantages of PVM is that it can be utilized in focusing on the long run relationship among macroeconomic factors and stock market. Campbell and Shiller (1988) perform a study in which they calculate the relationship among stock prices, expected dividends and earning. They found that dividends can be predicted by long term moving average of earning and for over several time periods the ratio of these earnings variable to current stock price is powerful in predicting stock returns, Further they found that these facts make stock prices and return too volatile.

A large number of studies are conducted about the relationship among macroeconomic factors stock returns in developed economies like USA, Japan and Europe markets by Chen, Roll and Ross (1986), Clare and Thomas (1994), Gjerde and Saettem (1999), Flannery and Protopapadakis (2002).Along with this in developing nation the same relationship was investigated in different developing markets such as Baily and Chung (1996), Kwon \& Shin (1999) and Ibrahim \& Aziz (2003). All these studies shows different results and main source of diversified result is the macroeconomic factor they select and the methodology the employed. Most of developing markets research focused on the East Asian countries of Asia. Regarding to Pakistan as developing country less of literature is available.

Regarding the literature available on stock market fluctuation and macroeconomic factors ups and downs is divided into some groups on basis of nature of markets. The first group covers the studies regarding the developed nations of the world. Chen, Roll and Ross (1986) organize a study of multifactor model regarding the economy of USA by taking macroeconomic factors. They found that change in risk premium, yield curve fluctuation and industrial production significantly explain the stock return, However further they explain that oil prices, consumption and market index does not affect stock market. Chen (1991) carry out a study which cover USA, his findings suggest some macroeconomic factors like industrial production growth rate, one month t-bills, term spread and dividends price ratio can be used in forecasting future market returns. Clare and Thomas (1994) performed a study in UK economy on multifactor based approach and after using 18 macroeconomic factors for checking its effect on stock market returns. They found that bank lending, corporate default risk, retail price index, and oil prices were important factors for United Kingdomstock market returns.

Second group contain those research studies which were done to study the response of variousto stock market returns in south Asian developing countries. Baily and Chung (1996) studied equity/stock market of Philippines and found that financial fluctuations, political changes and exchange rate movement cannot affect the Philippines stock market. Kwon \& Shin (1999) investigate the role of fundamental economic factors in evaluating the Korean stock market prices and found that stock returns were co-integrated with macro factors namely, trade balance, industrial production, money supply and foreign exchange. Ibrahim \& Aziz (2003) conduct a study on Malaysian economy to find out the response of stock prices to macro factors like inflation, industrial production, money supply and exchange rate. Inflation (CPI) and industrial output shows positive relation with stock prices while stock price relates negatively with exchange rate and money supply.

Third contain those studies which examine the situation for more than on country. Bilson, Brailsfoed and Hooper (2001) performed a study in which they investigate multi countries and for the study they used world market index (value weighted) and macro factors for explaining stocks market returns in selected emerging stock markets. On the basis of findings the study propose that world market returns and exchange rate are significant factor of stock market returns, while prices and real activities limitedly explain variations in returns and money related instruments have greater importance. A study regarding five ASEAN economies (Indonesia, Singapore, Philippines, Malaysia, and Thailand) was carryout by Wongbangpo and Sharma (2002) and they found that in short run stock market prices are function of current and past values of macro factors, while in long run stock prices positively relate to output growth (GDP/GNP).

\section{Theoretical background of study}

The interdependence among macroeconomic factors and stock market returns remained a subject of interest for independent researchers and academics. Mostly a common argument is sited that some fundamentals economic factors like inflation, industrial output, interest rate, money supply and exchange rate determined the stock market prices and affect the stock returns. Most of press releases related to finance indicate that investors in general believe that macroeconomic events (monetary policy, commercial policy) shows great affect on the stock price volatility. On the basis of this believe we can say that macroeconomic factors can affect the investment decision of investors, this motivates many researchers around the globe to inspect the interdependence between fundamental economic factors and stock returns. A number of research studies have attempted to check the effect of fundamental economic variables on stock prices and returns around the globe, Such as a theory developed by Ross (1976) named Arbitrage Pricing Theory (APT). Chen et al (1986) utilized some macroeconomic factors to check stock return behavior in the US stock markets. Again in 1986 Chen, Roll and Ross introduced the Multifactor's model or Macroeconomic Factors Model (MFM). Fama and French (1989) also contributed to stock market volatility measure. Literature also evidence cointegration analysis among macroeconomic factors and stock returns Mukherjee and Naka (1995), Kwon \& Shin (1999) etc. The current study utilized money supply, exchange rate, inflation, size of firm and GDP as macroeconomic factors to study the behavior of Karachi Stock Exchange (KSE) returns.

The selection of factors for current study is done carefully and theoretical importance of each factor is justified will. The justification of these factors is done through existing theories and literature. The current study utilized Autoregressive Distributed Lag (ARDL) model to capture the long run trend and dynamics of short run among macroeconomic factors and stock market returns in KSE.

\section{Inflation and stock prices}

As the correlation between actual inflation and unanticipated inflation will be positive, with ceteris paribus it will move stock prices in reverse direction. In other words the impact of inflation would be negative on the discount rate if rise cash flows occur at the same rate as inflation. De Fina (1991) findings suggest that due to pre-existing nature of contracts in stock market the immediate adjustment in firm's revenue and cost would be denied. It can be argue that initially when output price lag input cost response to inflation it should decrease cash flows.

\section{Gross domestic product (GDP) and stock prices}

There are numbers of measures to present economic performance of an economy such as GDP growth rate, GNP growth and industrial production index etc. Industrial production does affect the stock prices through the channel of the expected cash inflows Fama (1990). Thus the expected relationship between stock prices and GDP is positive.

\section{Exchange rate and stock market prices}

In case of emerging market the analysis of connection among exchange rate and stock market prices is interesting because the recent forefront of emerging markets to financial liberalization. Also the shipment of most of emerging markets from pegged arrangements to managed floating and to more flexible regimes. Dornbush and 
Fisher (1980) found that movement of currency affect balance of trade and international competitiveness which in turn disturbs the real income of an economy and this entire instability affects companies both current and future cash flows and their stock prices. Gavin (1989) findings show a different picture, that stock market prices movements may also affect the exchange rate through equities channel. According to monetarist exchange rate model the behavior of exchange rate may be affected by wealth of individuals through demand for money and equity is as a part of wealth. Branson (1983) and Frankel (1983) studies also traced the same link through portfolio balanced models.

\section{Size of firm (market capitalization) and stock prices}

Theoretically firm size does affect the firm assets valuation. Smaller stock has higher average returns. The diversification property and power of a firm makes it less risky than smaller one, so the larger the size if firm the larger will be the stock returns of a firm Benishy (1961) Rajan and Zingales (1995). Thus there is positive relationship among stock returns and size of firm. Introduction of size which works as a multiplicative term of dividends brings important advancement in the explanation of share prices Karathanassis and Philiappas (1988).In current study it is expected to have positive relationship among stock prices and size of firm.

\section{Money supply (MS) and stock prices}

Regarding money supply fluctuations and its impact on stock prices and returns remained controversial among economist. The controversies split these economists into two groups. One group of economist argued that there is a link among money market and stock prices. Variations in money supply causes wealth effects which in return change the current equilibrium of investor's portfolio, so when that starts re-adjusting their portfolio to achieve new equilibrium the price level of various assets changed. While studying Malaysian economy Habibullah (1998) found causality among money supply and stock market returns. Sprinkel (1964) found graphical relationship among supply of money and stock market returns for US economy. Other group says that if stock market is efficient. Mean that all the present and anticipated changes in supply of money will be included, so an underlying link between money supply and stock prices will not established. Further a change in MS will only alter the velocity of money and will not affect stock prices. US stock market was found to efficient with respect to MS variations. Kraft \& Kraft (1977) performed a study and found no association between stock market prices and money supply in United State (US). Habibullah and Baharumshah (1996) studied Malaysian economy using a trivariate co-integration (two-step) approach to test out whether money supply (MS) and output can be used to forecast stock market prices. They found no co-integration among output, money supply and stock markets.

\section{Data and methodology}

The current study utilize data ranging from 1971 to 2012 and in term of methodology the study utilize Autoregressive Distributed Lag (ARDL) frame work developed by Pesaran and Shin (1995, 1999), Pesaran et al. (1996) and Pesaran (1997). Before ARDL procedure Johnson Co-integration and Vector Error Correction Mechanism (VECM) method were used to examine the short run and long run relationship among factors, but this method has some flaws discussed by Pesaran et al. (2001). The table 01 shows the descriptive statistic of given data.

Table 1: Data description

\begin{tabular}{|c|c|c|c|c|c|c|}
\hline & Log KSE & Log GDP & INF & Log ER & LogM2 & SIZE \\
\hline Mean & 6.375399 & 14.58888 & 7.848649 & 3.144919 & 12.77265 & 0.129783 \\
\hline Median & 5.731819 & 14.64633 & 7.800000 & 3.077773 & 12.74037 & 0.023401 \\
\hline Maximum & 9.530426 & 15.50274 & 13.00000 & 4.221981 & 15.36076 & 0.766758 \\
\hline Minimum & 4.240463 & 13.61612 & 2.700000 & 2.161022 & 10.00148 & 0.003753 \\
\hline Std.Dev. & 1.593866 & 0.559306 & 3.311145 & 0.724221 & 1.572039 & 0.204202 \\
\hline Skewness & 0.410119 & -0.151 & -0.02064 & 0.125350 & -0.10649 & 2.017233 \\
\hline Kurtosis & 2.004268 & 1.830766 & 1.577615 & 1.493347 & 1.872800 & 5.901277 \\
\hline Jarque-Bera & 2.565752 & 2.248231 & 3.121694 & 3.596483 & 2.028746 & 38.07041 \\
\hline Probability & 0.277239 & 0.324940 & 0.209958 & 0.165590 & 0.362630 & 0.000000 \\
\hline Observations & 42 & 42 & 42 & 42 & 42 & 42 \\
\hline
\end{tabular}

\section{Determinants of Karachi stock exchange (KSE)}

\section{Basic model}

$\mathrm{Size}+\varepsilon_{\mathrm{i}}$

$\mathrm{KSE}=\alpha_{\mathrm{o}}+\beta_{1} \mathrm{ksc}(-1)+\beta_{2} \mathrm{GDP}+\beta_{3} \mathrm{ER}+\beta_{4} \mathrm{INF}+\beta_{5} \mathrm{MS}+\beta_{6}$

Where KSE is Karachi Stock Exchange, KSE-1 is Karachi Stock prices in previous period, GDP is Gross Domestic Product, ER is Exchange rate, INF is Inflation, MS is Money Supply (M1+M2) and Size is Size of the ith firm.

\section{Unit root tests}

Analysis with time series data was encountered by the term spurious regression. Mean without considering the level of stationarity of data series the result obtain through Ordinary Least Square (OLS) were meaningless. In this regard Engel and Granger (1987) proposed seven test statistics used for the calculation of level of stationarity of a data series calculated by OLS. In current study we only concentrate on the Augmented Dickey Fuller (ADF) test.

\section{Augmented dickey-fuller (ADF) test}

The Dickey-Fuller (DF) test used for the stationarity was augmented by introducing the lagged difference term of dependent variable on the basis of the assumption that series follow an Autoregressive AR (p) route, and the test procedure was named as ADF test.
ADF test proceeds basically as the DF test but with modified equation as:

$$
\begin{aligned}
& \Delta Y t=\alpha+\delta t+\gamma Y t-1+\phi \sum_{i=1}^{p} \Delta Y t-1 . \\
& \Delta Y t=\alpha+\gamma Y t-1+\phi \sum_{i=1}^{p} \Delta Y t-1
\end{aligned}
$$

With Null-Hypothesis of non-stationary or Ho: $\gamma=1$ (series is nonstationary)

\section{Long run relationship using auto regressive distributed lag (ardl) model}

The newly introduced robust method named as Auto Regressive Distributed Lag (ARDL) by Pesaran and Smith (1998), Pesaran and Shin (1999) and Pesaran et al. (2001) is utilized in this study to capture the long run relationship and short run dynamics of macroeconomic factors and stock prices. The motivation toward the use of this method is based on the advantages it have over the traditional Johnson Co-integration procedure. ARDL is based on general to specific modeling system. The ARDL procedure clearly identified the explained and explanatory variables of the model. Another advantage of ARDL method is that when the explanatory variables/factors are endogenous the estimation of model is possible (Pesaran and Shin 1999; Pearan et al. 2001). This method is applicable irrespective of either the factors are integrated of order 
zero or integrated of order one or fractionally co-integrated (Pesaran 1997).

The ARDL model for equation (1) is given as

$$
\begin{aligned}
& \Delta K S E t=\alpha+\delta 1 \sum_{i=1}^{p} \Delta K S E t-i+\delta 2 \sum_{i=1}^{p} \Delta L G D P t-i+\delta 3 \sum_{i=1}^{p} \Delta I N F t-i+\delta 4 \sum_{i=1}^{p} \Delta E R t-i+ \\
& \delta 5 \sum_{i=1}^{p} \Delta M 2 t-i+\delta 6 \sum_{i=1}^{p} \Delta M c a p / G D P t-i+\lambda 1 L G D P t-1+\lambda 2 I N F t-1+\lambda 3 E R t-1+\lambda 4 M 2 t-1+ \\
& \lambda 5 \text { Mcap } / G D P t-1+\mu
\end{aligned}
$$

Where $\alpha$ represent the drift component and $\mu$ is white noise error term (white noise). The error correction dynamic part of the equation (5) is the terms with summation sign and the remaining part of the same equation (5) shows the long run relationship.

Equation (5) is estimated by OLS for the ARDL model testing procedure and F-statistic value is obtained. This F-statistic value obtained from estimated equation (5) is compared with two sets of critical values calculated by Pesaran et al (2001) and Paresh Kumar Narayan (2005) for checking long run relationship in the model. Further the current study use Akaike's Information Criteria (AIC) for selection of appropriate model.

Null hypothesis of (no co-integration) in equation (5) is:

$\mathbf{H}_{\mathbf{0}}: \sum \lambda \mathrm{i}=0$

Alternative hypothesis of (existence of co-integration) in same equation is:

$\mathbf{H}_{1}: \sum \lambda \mathrm{i} \neq 0$

If calculations evidenced long run relationship in the model then the following long run model will be estimated.

$$
\begin{aligned}
& K S E t=\alpha+\delta 1 \sum_{i=1}^{p} K S E t-i+\delta 2 \sum_{i=1}^{p} L G D P t-i+\delta 3 \sum_{i=1}^{p} I N F t-i+\delta 4 \sum_{i=1}^{p} E R t-i+ \\
& \delta 5 \sum_{i=1}^{p} M 2 t-i+\delta 6 \sum_{i=1}^{p} M c a p / G D P t-i+\mu .
\end{aligned}
$$

In another step the short run coefficients and long run adjusting parameter will be estimated under ARDL approach as.

$$
\begin{aligned}
& \Delta K S E t=\alpha+\gamma 1 \sum_{i=1}^{p} \Delta K S E t-i+\gamma 2 \sum_{i=1}^{p} \Delta L G D P t-i+\gamma 3 \sum_{i=1}^{p} \Delta I N F t-i+\gamma 4 \sum_{i=1}^{p} \Delta E R t-i+ \\
& \gamma 5 \sum_{i=1}^{p} \Delta M 2 t-i+\gamma 6 \sum_{i=1}^{p} \Delta M c a p / G D P t-i+\eta E C t-i . .
\end{aligned}
$$

Where equation (7) $\eta$ shows the long run adjustment process of the model following a short run shock,

\section{Empirical findings and discussion}

\section{Testing of the unit root hypothesis}

One of the sufficient but not necessary conditions for cointegration is that the variable/factors should of the same order of integration (greater than zero) or has a deterministic trend (Granger 1986). In such regards the following table 1 represents the results of ADF test for stationarty level of selected factors. The result shows that all selected factors are stationary at first difference.

\section{ARDL System lag selection}

The ARDL co-integration system is implemented in two steps in the estimation of equation (1) for an emerging stock market (KSE) Pakistan using yearly data ranging from 1971-2012. In stage first unrestricted vector autoregressive (VAR) is used for obtaining the order of lag length through either Schwartz Bayesian Criteria (SBC) or Akaike Information Criteria (AIC).

Current study use AIC and minimum AIC suggest that the optimum lag length for given model is 2 . The results based on optimum lag length 2 the $\mathrm{F}$ statistic calculated is 9.60 which is greater than the upper bound table value with significance level $1 \%$. Mean null hypothesis can be rejected and accept that there is co-integration (long run relationship) in the model.

Table 1: Tests for Unit-Roots:s

\begin{tabular}{lll}
\hline & Level & First difference \\
\hline Without time trend & & \\
FACTORS & ADF & ADF \\
KSE(-1) & 3.560 & $6.69^{*}$ \\
Log GDP & 7.82 & $7.29^{*}$ \\
Inf & -0.62 & $-2.34^{*}$ \\
Log ER & -0.83 & $-4.48^{*}$ \\
Log M2 & -2.61 & $5.42^{*}$ \\
M.cap/GDP(size) & 1.67 & $-3.81^{*}$ \\
\hline With time trend & & \\
KSE(-1) & -0.73 & $-7.62^{*}$ \\
Log GDP & -0.18 & $3.23^{*}$ \\
Inf & -1.12 & $-8.84^{*}$ \\
Log ER & -2.06 & $-4.74^{*}$ \\
Log M2 & -1.71 & $-7.18^{*}$ \\
M.cap/GDP(size) & -1.96 & $-6.44^{*}$ \\
\hline Note: ${ }^{*}{ }^{* *}$, and ${ }^{* * *}$ shows significance at $1 \%, 5 \%$ and $10 \%$ level respectively.
\end{tabular}

Table 2: Lag length Selection and short run Diagnostic Tests

\begin{tabular}{lll}
\hline Order Of the lags & Akaiake Information criteria & $\begin{array}{l}\text { F-test } \\
\text { Statistics }\end{array}$ \\
\hline 1 & (AIC) & $6.57^{*}$ \\
2 & 25.20 & $9.60^{*}$ \\
\hline
\end{tabular}

Different Short-run (Diagnostic) Test-Statistics

Serial correlation LM, F =2.32 (.17)

$\mathrm{J}$-B Normality value $=1.74(0.28)$

Heteroscadesticity test $\mathrm{F}=64.61(.33)$

Ramsey RESET test=15.08 (.15)

Where $p$-values are in parenthesis

Table 3: Long Run ARDL results (Dependent Variable KSE (ARDL Order 1,0,1,1,0,2)

\begin{tabular}{lll}
\hline Factors & Coefficient & P-value \\
\hline KSE(-1) & 12.57 & 0.00 \\
Log GDP & .03 & 0.04 \\
Inf & -12.34 & 0.06 \\
Log ER & -15.51 & 0.01 \\
Log M2 & -8.30 & 0.04 \\
M.cap/GDP(size) & 3.25 & 0.08 \\
\hline
\end{tabular}

$\frac{M}{R^{2}=0.975214, R^{2} \text { adjusted }=0.959103, \text { F-statistics }=6053158(0.000),}$ Durbon Watson Stat $=2.041850$

Regressing KSE on GDP, INF, ER, M2 and size of firm obtained results are in table 03 . The results show each factor has expected sign and parameters of each factor is significant different level of significance. Both positive and negative relationships in the estimated model are found but it shows that in case of KSE the stock prices do depend on the macroeconomic factors. Further the long run findings suggest that all the taken factors are essential factors contributing to Karachi Stock Exchange (KSE).

\section{KSE previous values}

It shows positive relationship with its depended variable and is statistically significant. Mean that previous year performance of stock market enhances current year stock market activities.

\section{GDP (+)}

It is positively related to the KSE and is statistically significant. Mean GDP has positive impact on the KSE prices. It clarify that when the growth in an economy is favorable its will also stimulate the stock exchange activities and attract more investor to the stock exchange to invest and it will create a competitive environment in the stock exchange and it will also attract foreign investor to invest in the stock exchange. So in long run GDP relate with stock/ share prices. The same results were found by Maysami et al. (2004), Ratanapakorn and Sharma (2007), andAkbar et al. (2012).

\section{Inflation (-)}

It is statistically significant but relationship with KSE prices is nerative. It shows that when there is an inflationary trend in the 
economy it will adversely affect the stock/share prices. Inflation will increase the cost to the firms and initial cash flows will decrease and will curb the stock exchange activities and suppressed the stock exchange. Same results were found by Mittal (2011), and Akbar (2012).

\section{Money supply (-)}

Money supply is statistically significant but relationship with dependent variable is negative. Mean it will inversely affect the KSE prices. As money supply causes wealth effect and this wealth effect will disturb the on hand equilibrium in the investor's portfolio. So they will re allocate their portfolio for the existing situation and to achieve their new equilibrium portfolio but in this re allocating the price level of various assets changed. The findings are consistent with Fama (1981) and Mukerjee and Naka (1995). The negative sign also explain that KSE being an emerging economy stock market so it is not efficient to anticipate the change in money supply Rozeff (1974).

\section{Size of the firm (+)}

Size of firm mean ratio of market capitalization and GDP. It is statistically significant and is positively related the KSE price. So here the size shows the volume of turnover of a firm. Mean smaller the size higher will be the risk and higher will be the expected return but lesser number of investor will be available. When the size is larger so more power of diversification and lower the risk and attract more investor. So size of the firm will have positive impact on the KSE.

\section{Exchange rate (-)}

It is positively relates KSE is statistically significant. But literature evidenced both negative and positive impact of exchange rate on the stock prices. As when the value of domestic currency goes down so inflow to that country increases it stimulate the economic activities in the region and the foreign investor start investing in the domestic countries shares and stocks and stock exchange activities flourished but along with this investment the risk also increases and due to a non developed stock market the investor stop further investing and shrink the stock exchange. Akbar et al. (2012).

Table 4: Error correction mechanism (ECM) representation of ARDL model, Dependent Variable $\triangle \operatorname{KSEARDL}(1,0,1,1,0,2)$

\begin{tabular}{lll}
\hline Regressor & Coefficient & Prob- value \\
\hline KSE(-1) & 7.32 & 0.08 \\
$\Delta$ Log GDP & 0.20 & 0.00 \\
$\Delta$ Inf & 0.25 & 0.93 \\
$\Delta$ Log ER & -1.66 & 0.01 \\
$\Delta$ Log M2 & -12.63 & 0.61 \\
$\Delta$ M.cap/GDP(size) & 12.05 & 0.15 \\
EC $(-1)$ & -.58 & 0.02 \\
\hline
\end{tabular}

R-Squared $=0.73623$

Adjusted Squared $=0.63732$

F-stat. at $(6,27)=11.1647[.000]$

DW-statistic $=1.5133$

Table 4 shows error correction dynamics. The error correction term is statistically significant with correct sign. The estimated EC(-1) coefficient is -.58 and on the basis of data nature it says that $58 \%$ of correction is brought in disequilibrium in the present year. Further the results shows that GDP and ER significantly affect stock prices in short run, while other factors do not.

\section{Conclusion and policy options}

The current study examines the response of selected macroeconomic factors (Exchange Rate, Inflation, GDP, Size of Market and Money Supply) to the stock prices of Karachi Stock Exchange (KSE) of Pakistan. The study use annual data lengthen from 1971 to 2012. Regarding the methodology Autoregressive Distributed Lag Model (ARDL) is utilized to capture the long run short run response of macroeconomic factors toward Karachi Stock Exchange. As ARLD follow some restrictions. For this purpose unit root tests ADF (Augmented Dickey-Fuller) is used for checking the stationarity and non stationarity of the variables and the results of the test conforms that variables taken are stationary at their $1^{\text {st }}$ difference. After finding the integration order of variables/factors formal ARDL procedure was applied and the optimum lag length for model was find out through minimum AIC which ensure two (2) as the optimum lag length for the given model. The existence of co-integration between macroeconomic factors and stock prices was confirmed by the Wald test with optimum lag length two (2). The calculated value of F-test statistic is 9.62 which is greater than the upper bound critical table value generated by Pearson et al (2001). Thus it is concluded that in the model there is long run relationship among variables. For long run convergence and short run dynamics traditional Error Correction Mechanism (ECM) under ARDL approach is used.

In long run each factor shows statistically significant response toward stock prices of Karachi Stock Exchange. Further the ECM results shows that speed of adjustment is about $58 \%$ and is statistically significant and in short run GDP and Exchange Rate significantly affect the stock prices, while other factors were insignificant.

In term of policy option the study recommend that for smoothing of the stock prices fluctuations the given factors must be targeted by the policy makers. The finding of study suggest that proper management of the monetary policy is required to monitored the inflation so that volatility of stock prices can decreased, along with it exchange rate can also be targeted. Domestic productivity (GDP) can promote the capital and equity market of Pakistan, so such policies should be adopted that favors the encouragement of stock prices through domestic productivity growth.

\section{References}

Akbar, M., Ali, S., and Khan, M. F. (2012). The Relationship of Stock Prices and Macroeconomic Variables revisited: Evidence from Karachi Stock Exchange, African Journal of Business Management, 6 (4): 1315-1322.

Bailey, W., and Y. P. Chung, (1995), Exchange rate fluctuations, political risk, and stock returns: Some evidence from an emerging market, Journal of Financial and Quantitative Analysis 30, 541561.

Bilson, Christopher M., Timothy J.Brailsford and Vincent J. Hooper, (2001), "Selecting Macroeconomic Variables as Explanatory Factors of emerging Stock Market Returns", PacificBasin Finance Journal, Vol.9 pp. 401-426.

Branson, W. H. (1983). Macroeconomic determinants of real exchange rate, Cambridge University Press, Cambridge, MA.

Black, A., P. Fraser and R. MacDonald,(1997) "Business Conditions and Speculative Assets", Manchester School, 4, 379-393.

Campbell, J. Y. and R. Shiller (1988), Stock prices, earnings and expected dividends, Journal of Finance, 43, 661-676.

Charemza,W.W. - Deadman, D.F. (1992), New Directions in Econometric Practice: General to Specific Modeling, Cointegration, Aldershot: Edward Elgar.

Chen N.F. (1991), Financial Investment Opportunities and the Macro economy, Journal of Finance, Vol. 16, No. 2, pp. 529-553.

Chen, N. F., Roll, R. \& Ross, S. (1986). Economic forces and the stock market. Journal of Business 59(3): 83-403.

Cheung, Y. and L. Ng (1998), "International evidence on the stock market and aggregate economic activity", Journal of Empirical Finance, 5, 281-296.

Clare, A. D. and Thomas, S. N. (1994),'Macroeconomic Factors, the APT and the UK Stock Market', Journal of Business Finance and Accounting, 21, 309-330.

DeFina, R.H., (1991), Does Inflation Depress the Stock Market?, Business Review, Federal Reserve Bank of Philadelphia, 3-12.

Dickey, D. A. and W. A. Fuller (1981), Likelihood ratio statistics for autoregressive time series with a unit root. Econometrica, Volume 49, pp. 1057-72.

Dornbusch, R., \& Fischer, S. (1980). Exchange rates and current account. American Economic Review, 70, 960-971.

Fama E.F. (1981), Stock Returns, Real Activity, Inflation and Money, American Economic Review, Vol. 71, No. 4, pp. 545-565. 
Fama, E.F. and M. Gibbons. (1982) Inflation, Real Returns and Capital Investment, Journal of Monetary Economics, , Vol. 9, No. 3 , pp. 545-565.

Fama, E. F., (1990). Stock Returns, Expected Returns, and Real Activity, Journal of Finance 45, pp. 1089-1108.

Fama, E. F., and K. R. French, (1989). Business Conditions and Expected Returns on Stocks and Bonds, Journal of Financial Economics 25, pp. 23-49.

Fama, E.F. (1991)Efficient Capital Markets: II, Journal of Finance, Vol. 46, No. 5, December, pp. 1575-1617.

Ferson, W. and C. Harvey, (1991), "The variation of economic risk premiums," Journal of Political Economy99, 385-415.

Frankel, J. A. (1983) Monetary and Portfolio-Balance Models of Exchange Rate Determination. In J. S. Bhandari and B. H. Putnam (eds) Economic Interdependence and Flexible Exchange Rates. 84-115

Flannery, M. J. \& Protopapadakis, A. A. (2002), “ Macroeconomic factors do influence aggregate stock returns" , The Review of Financial Studies, 15, 3, 751-782

Gavin, M. (1989). The stock Market and exchange rate dynamics. Journal of international money and finance, 8, 181-200.

Gjerde, O. and F. Saettem.(1999) Casual Relations among Stock Returns and Macroeconomic Vari-ables in a Small, Open Economy, Journal of International Finance Markets Institutions and Money, Vol. 9, pp. 61-74.

Habibullah, M. (1998) Money, Output, Stock Prices in Malaysia: Further Evidence. Borneo Review135-155.

Habibullah, M., and A. Baharumshah (1996) Money, Output, Stock Prices in Malaysia: An Application of Cointegration Tests. International Economic Journal121-130.

Ibrahim, M. H. and W. S. W. Yusoff (2001), Macroeconomic variables, exchange rate, and stock price a Malaysian perspective. IIUM Journal of Economics and Management, Volume 9(2), pp. 141-63.

Karathanassis-Philippas (1988) Estimation of Bank Stock Price Parameters and the Variance Components Model. Applied Economics20:3, 497-507.

Kraft, J., and A. Kraft (1977) Determinants of Common Stock Prices: A Time Series Analysis. Journal of Finance417-725.

Kwon, C.S. and T.S. Shin.(1999) Cointegration and Causality between Macroeconomic Factors and Stock Market Returns, Global Finance Journal, Vol. 10, No. 1, pp. 71-81.

Lintner, John.(1965)a."The Valuation of Risk Assets and the Selection of Risky Investments in Stock Portfolios and Capital Budgets." Review of Economics and Statistics. February, 47, pp. 13-37.

Lintner, John.(1965)b. "Security Prices, Risk and Maximal Gains from Diversification.” Journal of Finance.December, 20, pp. 587615.

Maysami, R.C. and T.S. Koh A (2000). Vector Error Correction Model of the Singapore Stock Market, International Review of Economics and Finance, Vol. 9, pp. 79-96.

Maysami, R. C., Howe, L. C. \& Hamzah, M. A. (2004). Relationship between Macroeconomic Variables and Stock Market Indices:
Cointegration Evidence from Stock Exchange of Singapore's All-S sector Indices. Journal Pengurusan, 24, 47-77.

Merton, R. (1973). An intertemporal capital asset pricing model. Econometrica, 41, 867-887. http://dx.doi.org/10.2307/1913811

Mossin, Jan.(1966)."Equilibrium in a Capital Asset Market." Econometrica. October, 35,pp. 768-83.

Mukherjee T.K. and A. Naka.(1995) Dynamic Relations between Macroeconomic Factors and the Japanese Stock Market: An Application of a Vector Error Correction Model, Journal of Financial Research, 1995, Vol. 18, No. 2, pp. 223-237.

Mukherjee, T. K. \& Naka, A. (1995). Dynamic relations between macroeconomic factors and the Japanese stock market: an application of a vector error correction model. The Journal of Financial Research 18(2): 223-237.

Mundell, R.A.(1963) Inflation and Real Interest, Journal of Political Economy,Vol. 71, No. 3, June, pp. 280-283.

Pesaran MH, Shin Y, Smith RJ, (2000), "Structural analysis of vector error correction model with exogenous I(1) factors", Journal of Econometrics,97, 293-343

Pesaran MH.,Shin Y, (1999), “An Autoregressive Distributed lag Modeling Approach to contraption Analysis" Chapter 11 in Econometrics and Economic Theory in the 20 Century: The Ragner Frisch Centennial Symposium. Strom S (ed). Cambridge University Press: Cambridge.

Pesran, M.H.,Pesran B, (1997), with microfit 4.0 An interactive Approach", Oxford University Press :Oxford.

Phillips, P.C. and Perron, P, (1988), Testing for a unit root in a time series regression, Biometrica, 75, 335-346.

Ratanapakorn, O. and Sharma, S. C. (2007), "Dynamic analysis between the US stock returns and the macroeconomic variables", Applied Financial Economics, 17:5,369-377

Ross, S. A. (1976). The arbitrage theory of capital asset pricing. Journal of Economic Theory 13: 341-360.

Rozeff, M. (1974) Money and Stock Prices. Journal of Financial Economics245-302.

Rajan, R.G. and Zingales, L. (1995) What Do We Know about Capital Structure? Some Evidence from International Data, Journal of Finance, 50(5), 1421-60.

Schwetz, W. (1989) Tests for Unit Roots: A Monte Carlo Investigation, Journal of Business and Econometric Statistics, Vol. 7, No, 2, pp. 147-159.

Schwert, G. W. (1989), Why Does Stock Market Volatility Change Over Timee, TheJournal of Finance, Vol. 44, No. 5, pp. 11151153 [Online] Available at: http://www.jstor.org/stable/pdfplus/2328636.pdf [Accessed 29 June 2009].

Sharpe, William F.(1964) "Capital Asset Prices: A Theory of Market Equilibrium under Conditions of Risk.”Journal of Finance. 19:3, pp. $425-42$

Sprinkel, Beryl W. (1964) Money and Stock Prices (Richard D. Irwin, Inc., 1964).

Wongbangpo P, Subhash CS (2002). Stock Market and Macroeconomic Fundamental Dynamic Interactions: ASEAN-5 Countries, J. Asian Econ., 13: 27-51. 